\title{
$O$ conceito de processo justo na reforma do processo matrimonial e no processo penal ${ }^{1}$
}

\author{
The concept of a fair process in the reform of the matrimonial process \\ and in the penal process
}

Resumo: A progressiva canonização das instituições judiciais; a justiça no proceder nas causas de nulidade matrimonial; a ênfase excessiva atribuída ao poder judicial episcopal; o novo processo mais breve; a intervenção de defensores das partes; a missão pastoral especializada e a deontologia profissional específica; o ideal de gratuidade e a liberdade de op-

\section{Manuel Jesús Arroba Conde ${ }^{2}$}

Abstract: The progressive canonization of judicial institutions; the justice in proceeding in the causes of marriage nullity; the overemphasis on the episcopal judiciary; the new process is shorter; the intervention of defenders of the parties; the specialized pastoral mission and specific professional deontology; the ideal of gratuity and the freedom of

1 Primeira conferência proferida no II Simpósio Canônico "Questões seletas de Direito Matrimonial e Penal Canônico", promovido pelo Instituto Superior de Direito Canônico Santa Catarina em 8-9 de maio de 2018.

2 Presidente, Professor e Doutor no Institutum Utriusque Iuris da Pontificia Universidade Lateranense de Roma. Recentes publicações do autor sobre o tema da conferência: com C. IZZI, Pastorale giudiziaria e prassi processuale nelle cause di nullità del matrimonio dopo la riforma operata con il Motu proprio Mitis Iudex Dominus Iesus, Cinisello Balsamo 2017, 320 pp; com M. RIONDINO, Introduzione al diritto canonico, Milano 2016, 217 pp.; 2017 (2a ed.), 230 pp; Giusto processo e peculiarità culturali del processo canonico, Roma 2016, 200 pp; La problematica giuridico-canonica sul matrimonio e la famiglia nell'orizzonte della giustizia e della misericordia. Aspetti processuali, in Atti della Consociatio Internationalis Iuris Canonici, Roma 2019, pp. 415-435; Il Vangelo dell'amore tra coscienza e norma. Aspetti giuridici, in G. AUTIERO, Per una nuova cultura pastorale. Il contributo di Amoris Laetitia; El concepto de proceso justo en la reforma del proceso matrimonial y en el proceso penal, in SADEC, XV Jornadas anuales, Buenos Aires 2018, pp. 19-42; Il m.p. Mitis Iudex Dominus Jesus in relazione al concetto di giusto processo, in ARCISODALIZIO DELLA CURIA ROMANA, Quaestiones selectae in re matrimoniali ac processuali, Città del Vaticano 2018, pp. 9-34; La giusta mercede dell 'avvocato ecclesiastico, in Monitor Ecclesiasticus CXXXI (2016), pp. 487-499. 
ção na designação do advogado; a justiça no proceder nas causas penais; algumas propostas contra o risco de injustiça no proceder; os riscos do excessivo recurso à via extrajudicial.

Palavras-chaves: Processo matrimonial. Processo penal. Processo mais breve. Deontologia profissional. Via extrajudicial. choice in the appointment of the lawyer; justice in criminal proceedings; some proposals against the risk of injustice in doing so; the risk of excessive recourse to extrajudicial proceedings.

Keywords: Matrimonial process. Penal process. Briefer process. Professional ethics. Extrajudicial way.

\section{Introdução}

No estudo das normas processuais canônicas, o conceito de justo processo, ou do devido processo, presente na normativa internacional, pode ser considerado um princípio hermenêutico e, portanto, um critério muito autorizado de avaliação da práxis de administração da justiça na Igreja ${ }^{3}$. Esta ideia não obedece a um modismo do momento que induz a atividade dos tribunais eclesiásticos a se ajustar, por mera conveniência, ou por simples imitação, aos critérios dos tribunais seculares. Trata-se de algo mais profundo que tentarei expor no primeiro momento desta reflexão, antes de passar ao segundo e terceiro momentos, nos quais me concentrarei sobre a questão da incidência que tal conceito tem na aplicação das normas sobre a reforma do processo de nulidade matrimonial e naquelas relativas ao processo penal.

\section{A progressiva canonização das instituições judiciais}

A proposta de assumir nos processos canônicos o conceito de justo processo como critério hermenêutico útil tem como marca profunda a história, devido à progressiva implantação, na práxis da Igreja primitiva, de alguns elementos próprios da atividade processual e ao contexto no qual as comunidades cristãs foram se expandindo. O pro-

3 Para um estudo mais amplo, cfr. M. J. Arroba Conde, Giusto processo e peculiarità culturali del processo canonico, Roma 2016; sobre a consideração do conceito de justo processo como critério hermenêutico, cfr. ibidem, 15-24. 
fessor Javier Belda afirma em um dos seus estudos ${ }^{4}$ que as primeiras notícias a esse respeito remontam à Didascalia Apostolorum, bem antes da Episcopalis Audientia, momento em que com frequência os autores costumam destacar como sendo o verdadeiro início de um processo canônico e sobre cujo significado e alcance existem teorias contrapostas $^{5}$.

$\mathrm{Na}$ realidade, seja pelo normal e compreensível surgimento precoce de algumas dimensões maiores ou menores entre os fiéis, seja pelo papel que, a esse respeito vai sendo pouco a pouco reconhecido aos responsáveis pela comunidade, cabe encontrar vestígios de uma atividade processual eclesiástica no nascimento mesmo da comunidade. É suficiente reflexo disso as palavras do Evangelho e das Cartas de Paulo, quando convidam a enfrentar a resolução das controvérsias entre irmãos, recorrendo à própria comunidade, evitando "atuar como os pagãos". Poderia se pensar que tal exortação confirmasse uma presunção, segundo a qual, a justiça administrada por juízes da sociedade civil, com suas solenidades, constituísse um obstáculo para o ideal de se estabelecer a justiça animada pela caridade, a reconciliação ou o desejo de se entender. Se tal dedução se considera exagerada, poderá se dizer, ao menos, que as recomendações evangélicas e paulinas presumem que buscar soluções internas para enfrentar a injustiça, com procedimentos tão elementares como dirigir-se primeiro ao irmão e, depois, aos responsáveis pela comunidade, constitui uma garantia a mais para se alcançar os objetivos desejados de justiça.

A Didascalia Apostolorum, ao oferecer notícias sobre a precoce incorporação de um conjunto de disposições disciplinares relativas ao modo de proceder nas declarações (estabelecendo as questões referentes ao lugar, à hora, à diferenciação de tempos...), obriga-nos a descartar uma consideração pouco positiva que, ao menos em relação às resoluções de justiça dentro da comunidade, possa ser atribuída apressadamente às palavras do Evangelho e das Cartas Paulinas. Em outras palavras: cabe pensar que o ideal de uma justiça animada pela carida-

4 Cfr. J. Belda, El ministerio judicial del Obispo hasta el surgimiento de la Lex Christiana (ss. I-IV), en Anuario de Derecho Canónico 4 (2015), 395-396.

5 Como reconhecimento de poder judicial (Proff. Vismara y Cima) ou somente arbitral entre fiéis (Prof. Cuena Buey). 
de e pelo desejo de reconciliação foi logo cedo percebido na Igreja primitiva, não apenas como um ideal compatível com as solenidades típicas do fenômeno processual, mas, inclusive, como um objetivo difícil de alcançar sem desenvolver e incorporar adequadamente tais solenidades ${ }^{6}$.

$\mathrm{Na}$ etapa em que a jurisdição eclesiástica começa a se estender, constata-se que as formalidades típicas da instituição processual não foram entendidas como um obstáculo para anunciar a Justiça (com maiúscula), também por meio dos pronunciamentos de justiça voltados para a resolução das controvérsias e, portanto, é certo que as solenidades processuais foram um válido auxílio para o exercício do ministério judicial episcopal. A respeito desta questão é suficiente se reportar ao dado mais substancial que, desde um ponto de vista sistemático, reflete os dados históricos. Refiro-me ao progresso que pode e deve representar a opção por manter uma adequada coerência com as culturas processuais seculares para uma melhor administração da justiça na Igreja ${ }^{7}$.

Formulamos agora este fenômeno, referindo-o às chaves da imprescindível reciprocidade que caracteriza a obra da evangelização em qualquer âmbito. Em relação ao nosso, podemos afirmar que a Igreja, enquanto evangeliza a cultura judicial desde sua condição e missão como testemunha da Justiça, resulta, por sua vez, evangelizada, isto é, enriquecida pelos elementos positivos que outros ordenamentos processuais foram amadurecendo para melhorar os modos de pronunciar justiça nas situações controvertidas.

Este dado pode nos permitir refletir sobre algumas circunstâncias atuais em relação às quais seria um erro se a justiça eclesiástica se afastasse desta abordagem de fundo.

Embora suscetível de instrumentalização demagógica, creio que o ideal do justo processo é o conceito que melhor exprime hoje as garantias mínimas exigidas pelas normas internacionais para considerar

6 Cfr. M. J. Arroba Conde - C. Izzi, Pastorale giudiziaria e prassi processuale nelle cause di nullità del matrimonio, Cinisello Balsamo 2017, 47-62.

7 Cfr.Id., Giusto processo, 12-13. 
aceitável, em seu modo de proceder, a administração da justiça ${ }^{8}$. Ajustar-se a este ideal mínimo deveria ser considerado um dever inegociável nas normas processuais e na práxis forense da Igreja. Isso comporta apostar em manter a via judicial nas situações de conflito quando está em jogo direitos subjetivos controvertidos, violados ou suscetíveis de restrição penal. Manter esta via implica na necessidade de conservar as características próprias de todo poder judicial: a fidelidade em relação à quaestio iuris e a certeza moral em relação à quaestio facti ${ }^{9}$.

Trata-se de uma aposta coerente, não só com a referida dinâmica de reciprocidade própria da evangelização, mas, também, com a melhor tradição da história da Igreja que assumiu, desde muito cedo, o desafio de exercer um poder judicial reconhecido externamente, para ajudar aos mais desfavorecidos, sobretudo, quando a atividade judicial era objeto de menor atenção por parte dos poderes seculares, mais ocupados em defender fronteiras e outros tipos de interesses. Pode-se afirmar que a atividade judicial eclesiástica chegou a ser um sinal do compromisso da Igreja para com os mais necessitados, evitando que no esforço por resolver as controvérsias prevalecesse o direito da força no lugar da força do direito. É suficiente se referir ao Concílio de Macôn (séc. V) o qual, dentre as resoluções tomadas, decidiu liberar as miserabiles personae da jurisdição exercida pelos oficiais reais, cheia de ira e prepotência ${ }^{10}$. Por outra parte, manter como via judicial a via processual permite não se desvincular do sentido de justiça do qual são reflexo os sistemas seculares.

Aspirar pela justiça não é patrimônio exclusivo do crente, por isso, vale a pena fazer com que as decisões eclesiásticas sejam com-

8 Como normas internacionais mais universais cabe se referir aos artigos 8 e 10 da Declaração universal dos direitos humanos proclamada pela ONU em 1948, assim como o artigo 4 do Pacto internacional sobre direitos civis e políticos de 1966.

9 Sobre essas características e a correspondente profunda diferença entre o modo de proceder judicial e extrajudicial, cfr. M. J. Arroba Conde - M. Riondino, Introduzione al diritto canonico, Milano (2 ed.), 2017, 187.

10 Cfr. Concilium Matisconense II, Canon VII, en J.D. Mansi (ed.), Sacrorum Conciliorum nova et amplissima collectio, IX, rist., Graz, 1960, coll. 952-953; Canon XII, in ivi, coll. 954-955. 
preendidas e, inclusive, reconhecidas por outros ordenamentos, sem colocar em perigo estas realizações, como poderia ocorrer se tais decisões deixassem de ser proveniente de um justo processo, cujas bases são o contraditório entre as partes e a imparcialidade do juiz.

Às partes corresponde o ônus de, em condições de igualdade, provar o que for necessário para resolver as controvérsias, conforme o exige o direito de defesa em seu duplo conteúdo: como direito a ser informado e a ser escutado, podendo exercitá-lo com a devida assistência técnica. Ao juiz competente segundo a lei (para evitar desigualdades que decorreria de um juízo instaurado ad personam), se confia a gestão dinâmica do processo, as decisões endo-processuais e a resolução final, mas em posição imparcial, isto é, segundo o princípio de estrita legalidade, com a obrigação de motivar as decisões, de tomá-las dentro de um tempo razoável e com a possibilidade de serem impugnadas ao menos uma vez ${ }^{11}$.

Interessa-nos agora fazer notar que o valor de manter a vida judicial na atual práxis processual da Igreja, está sendo submetido a uma dura prova, particularmente nas causas de nulidade matrimonial e nas causas penais. Trataremos de cada uma delas separadamente.

\section{A justiça no proceder nas causas de nulidade matrimonial}

Nas causas de nulidade matrimonial, objeto de uma recente reforma processual, a aposta pela manutenção exclusiva da via judicial foi o fruto de uma progressiva reflexão durante o discernimento efetuado nos Sínodos sobre a família. Neles, foram formuladas propostas alternativas à vida judicial, inicialmente preferida por muitos, tais como um juízo levado a cabo no foro da consciência, ou, então, um processo extrajudicial, chamado de administrativo, enquanto proposto em termos semelhantes aos que no cân. 50 se estabelecem para decisões de governo que não requer regras processuais obrigatórias por lei, mas

\footnotetext{
11 Algumas das questões de fundo, nas quais se vai desgranando o valor substancial do justo processo, como são as que se referem às provas, às motivações das sentenças e à natureza judicial do novo processo mais breve, serão objeto de outras conferências que me foram confiadas nestas jornadas, razão pela qual prescindo de entrar nelas agora.
} 
somente aquelas que a mesma autoridade (a que deve decidir) julga útil seguir para comprovar os dados necessários e resolver a questão de fundo. Visto que a nova lei manteve a via judicial, a preocupação se volta para assegurar uma práxis que se ajuste a seus princípios. Em meu entendimento tais princípios podem correr alguns perigos, especialmente em relação a algumas questões muito concretas: antes de tudo, no que se refere à excessiva ênfase dada à dimensão judicial do ofício episcopal, à interpretação do novo processo denominado breviore coram episcopo (denominação muito infeliz) e à presumida tensão entre a dimensão pastoral do processo e suas características técnicas, comum a todo fenômeno processual, especialmente no que tange à necessidade, ou não, de as partes terem defensores.

\subsection{A ênfase excessiva atribuida ao poder judicial episcopal}

Quanto ao poder judicial episcopal, é necessário se referir à determinação feita por lei do juiz competente, indispensável em um justo processo. Nesta problemática, deve-se ter em conta o modo como o ordenamento canônico provê a garantia dos valores que na maioria dos ordenamentos jurídicos se pretendem tutelar com o princípio da separação de poderes: a submissão do mesmo poder ao império da lei em um estado de direito, o controle da arbitrariedade e a exclusão do abuso no exercício do poder público.

No ordenamento canônico se afirma, como princípio, a unidade do poder de jurisdição, com a aplicação somente moderada do princípio de separação das distintas esferas do poder eclesiástico (cân. 135). Isso implica que o Bispo diocesano e o Papa, além de pastores, legisladores e superiores em seus respectivos âmbitos de responsabilidade, sejam, por sua vez, juízes natos, isto é, titulares de um poder próprio na esfera judicial. Como juízes próprios, a lei lhes confia algumas causas e lhes consente que possam reservar a si as que julgarem oportuno. Todavia, para evitar que esta titularidade e responsabilidade degenere em arbitrariedade, contrária ao princípio de legalidade (que é a que caracteriza de maneira mais intensa o poder judicial), o ordenamento estabelece, ao mesmo tempo, estruturas e ofícios com poder judicial vicário e ordinário, isto é, exercido em nome do titular do poder 
próprio (que erige e governa a estrutura e confere os ofícios). O poder judicial vicário está diretamente determinado por lei em suas atribuições e competências, sem a necessidade de receber delegação específica do juiz próprio ${ }^{12}$.

Com isso não esquecemos que está entre os "critérios fundamentais" da reforma a valorização da dimensão judicial do ofício do Bispo diocesano. Quero insistir ainda mais no fato de que tal valorização não supôs uma modificação essencial na disciplina. São somente três as novas atribuições do Bispo diocesano: a possibilidade de nomear juízes leigos, de confiar a causa a um juiz único, se não for possível formar o colégio (sem a necessidade de obter a permissão da conferência episcopal estabelecido pelos cânn. 1421 e 1425), e de decidir nas causas tratadas no processo brevior. Das três, somente a última comporta o exercício pessoal do poder judicial. Segue, pois, sendo critério prevalente que a responsabilidade episcopal não deve traduzir-se, na maioria dos casos, no exercício direto do seu poder judicial, mas, sim, na destinação aos estudos especializados de um maior número de pessoas (clérigos e leigos) e em um esmerado seguimento pessoal do habitual exercício vicário do mesmo poder ${ }^{13}$. Essa orientação responde ao primado da norma missionis, pois a atividade judiciária recai sobre direitos controvertidos entre pessoas físicas ou jurídicas, sugerindo que se evite a implicação pessoal do Bispo com o intuito de proteger a sua missão pastoral em benefício de todos os fiéis ${ }^{14}$.

A necessidade de facilitar o acesso aos processos é afirmada no mesmo Proêmio. No conjunto do corpo normativo se adverte a respeito da conexão entre acessibilidade e proximidade das estruturas judiciárias. Os critérios de proximidade e acessibilidade comportaram a

\footnotetext{
12 A respeito da relação entre o poder judicial e as demais esferas do poder de jurisdição no ordenamento canônico, cfr. M. J. Arroba Conde, Diritto processuale canonico, Roma (6 ${ }^{\mathrm{a}}$ ed.), 2012, 86-96.

13 Cfr. M. J. Arroba Conde - C. Izzi, Pastorale giudiziaria, 22-27.

14 Quanto ao conceito de norma missionis como orientação na compreensão do direito canônico, cfr. M. J. Arroba Conde - M. Riondino, Introduzione al diritto canonico, 1-3; P. Gherri, Lezioni di teologia del diritto canonico, Città del Vaticano 2004.
} 
modificação da disciplina sobre os títulos de competência relativa ${ }^{15}$, mas não se pode afirmar o mesmo em relação às normas universais que regem a ereção de tribunais em que são tratadas as causas de nulidade matrimonial. As novas disposições se limitam a fazer algumas integrações ao CIC 1983 já colocadas em prática, porque conformes à 1 ei ${ }^{16}$.

\subsection{O novo processo mais breve}

No que se refere ao novo processus breviore coram episcopo, limito-me a advertir agora ${ }^{17}$ que este processo não se celebra ante o Bispo, pois a ele só se confia a decisão. Os atos processuais prévios seguem sendo tarefa das estruturas e ofícios do poder judicial ordinário e vicário: a admissão corresponde ao vigário judicial e as provas se produzem perante o instrutor ${ }^{18}$. Nas normas, a brevidade se refere apenas ao tempo máximo para fixar e realizar a audiência para adquirir as provas, depois do decreto com o qual se formula o dubium (30 dias), mas não é certo que a brevidade alcance a resolução, pois o Bispo pode decidir remeter a causa para o processo ordinário. Na realidade nenhuma norma impede que também nos processos ordinários se fixe o início da fase instrutória em um prazo breve, se bem que é menos previsível que se possam adquirir as provas em uma única sessão. Teria sido melhor chamar este processo, tal como se propôs no Sínodo, de processo judicial extraordinário, deixando fora de dúvida de que se trata de processo que, embora prevendo uma investigação sumária, é

15 Passaram a ser seis, e não mais cinco (incluindo o quase-domicílio do demandante) e foram suprimidos os requisitos que se estabeleciam para se recorrer ao foro do demandante e das provas.

16 A integração faz referência à possibilidade de que um Bispo, por falta de recursos de pessoal, decida confiar a atividade judicial de sua diocese a um tribunal mais próximo, sem com isso criar uma estrutura comum (como é o caso do tribunal interdiocesano). Para os demais aspectos, o can. 1673, $\S 6$ se remete expressamente aos cânones 1438-1439.

17 Outros aspectos serão tratados na conferência que tem por tema específico o estudo da via processual.

18 Cfr. M. J. Arroba Conde, La relazione tra potestà giudiziale episcopale e uffici tecnici nel processo brevior, en Av.Vv., Studi in onore di Carlo Gullo, Città del Vaticano 2018, 777-798. 
regido pelos princípios da atividade judicial e ao qual se deve recorrer em casos excepcionais.

\subsection{A intervenção de defensores das partes}

Entre as garantias de um justo processo encontra-se a livre designação de um defensor entre os admitidos pelo respectivo tribunal. A importância de contar com defensores válidos nos processos logo foi percebida na história da Igreja. Segundo o professor Ochoa ${ }^{19}$, o título de Advocatus christianorum remonta ao ano 177, quando na região de Lion um advogado, chamado Vettius Epagatus, cristão na clandestinidade, que assistia a um juízo realizado contra outros cristãos, reprovou ao juiz por não estar procedendo segundo as leis romanas ao não ter-lhes concedido um defensor. Então, ele mesmo se dispôs a ser o advogado, conseguindo demonstrar que as acusações eram falsas, exceto a de serem cristãos. Com sua conduta, Vettius se antecipa ao que mais tarde seria a missão do Defensor civitatis seu plebis, nascida no baixo império (perto do ano 364) e regulamentada por Valentiniano e Valente para frear os abusos dos potentiores, dos funcionários e, também, dos magistrados. A mesma lógica inspirou uma petição formulada no Concílio de Cartago do ano 401, quando os Bispos africanos solicitaram do poder imperial a constituição, mediante provisão do Bispo, de um Defensor pauperum. Em dita instituição se funda a figura dos sete defensores regionais organizada em Roma por Gregório Magno no ano 598. Para a defesa de seus mesmos interesses e patrimônio, perto do ano 407, a Igreja solicitou, e obteve, a instituição da figura do Defensor ecclesiarium, reforçada em suas atribuições pelos imperadores Honório e Teodósio, cuja missão consistia na defesa dos interesses da Igreja no foro civil, embora sempre legum ordine servato. Representa, pois, um grave retrocesso na cultural processual da justiça eclesiástica que se propaguem ideias ou práticas forenses de obstáculo à intervenção eficaz dos advogados, defensores das partes, sem que caiba justificar este proceder a partir de presumidas razões

19 A respeito desta interesante questão, cfr. J. Ochoa, La figura canónica del procurador y abogado público, en M. Basso (ed.), Opus Iustitiae Pax. Miscellanea in onore del prof. Xavier Ochoa, Città del Vaticano 1990, 209-241. 
pastorais. Estas não podem ser entendidas como contrapostas à diversidade dos papéis no processo, que resulta necessária em qualquer cultura processual para se conseguir uma comprovação razoável da verdade. Nem por isso se desvirtua a necessidade de promover, como parte da deontologia forense, uma adequada preparação técnica, uma maior consciência do papel pastoral, não só profissional, que os advogados desempenham nas causas, vista a sua natureza específica ${ }^{20}$.

A preparação de válidos defensores é essencial para um bom andamento do processo. Ao se revisar o CIC, os cânn. 1559 e 1678 foram saudados como um grande acerto, pois, sem equiparar as faculdades das partes públicas e privadas, estabeleciam uma equiparação em relação às faculdades dos seus advogados, entendida em benefício de uma defesa técnica mais adequada, pontual e eficaz. A lei qualifica como um direito sua presença nos interrogatórios (nos que participam ativamente, podendo colocar novas questões através do juiz) e a supervisão dos autos, antes mesmo do decreto de sua publicação. A lei permite ao juiz interrogar sem estas garantias somente por razões e circunstâncias que, em boa lógica, devem ser consideradas excepcionais. Não há qualquer justificativa que a exceção se converta em regra, desvirtuando-se esta realização do código do Concílio, uma vez que estão em jogo aspectos essenciais do justo processo.

As novas disposições sobre a preparação da causa reforçam a ideia acerca da configuração teórica do papel do advogado no processo canônico como uma missão também pastoral, embora desde a sua especialização, o que reafirma a especificidade canônica de sua deontologia, profissional ${ }^{21}$. Ao mesmo tempo, as exigências entre processo canônico e valores do justo processo, derivadas da norma missionis, esclarece a conexão entre o direito à assistência técnica e o ideal de

20 Quanto a deontología específicamente canônica do advogado, cfr. M. J. Arroba Conde, Deontología forense canónica, en Curso de derecho matrimonal y procesal canónico para profesionales del foro, XIX, Salamanca 2009,31-65.

21 No que se refere ao novo impulso que, em meu entendimento, deve receber o papel dos defensores depois da reforma, sobretudo para fazê-la caminhar bem, cfr. M. J. Arroba Conde, La pastoral judicial y la preparación de la causa en el motu proprio Mitis Iudex Dominus Iesus, en M. E. Olmos Ortega, Procesos de nulidad matrimonial tras la reforma del Papa Francisco, Madrid 2016, 63-82. 
gratuidade dos processos à qual se faz menção nos textos sinodais e em algumas intervenções papais ${ }^{22}$.

2.3.1. A missão pastoral especializada e a deontologia profissional específica

Não são adequadas as duas teorias com as que se tentou definir, com maior frequência, a função do patrono. A primeira é a que o vê como nuntius da parte, isto é, um simples transmissor da vontade do seu assistido ao organismo judicial, tendo a tarefa de enquadrá-la em formas jurídicas aceitáveis. A segunda teoria é a da representação, apoiada em um mandato procuratório, como se este pudesse ser entendido como um contrato em virtude do qual o mandatário assume a obrigação de realizar atos jurídicos no exclusivo interesse do mandante. $\mathrm{Na}$ realidade, a fonte dos antes do mandatário em um processo é a lei processual, enquanto o peso da vontade do mandante se reduz a uma mera designação do mandatário e a correspondente possibilidade de substituí-lo. Disso se deduz com clareza que o papel do advogado não é o de intérprete, nem o de mandatário, nem o de mero representante. A lei canônica o qualifica como munus (cânn. 1484 e 1490), como oficium (cânn. 1488 e 1489) e como ministerium (cân. 1481). Cada uma destas expressões possui suas próprias nuances, mas coincidem em sublinhar que a configuração teórica mais adequada é sempre a norma missionis.

Atendo-se a uma sã interpretação das normas, chamar de missão a função do advogado, significa se referir a uma relação jurídica de complexa colaboração, que não se reduz à cooperação entre o defensor e a parte para obter os objetivos compartilhados somente por eles, mas inclui a consecução dos valores últimos do ordenamento, a cujo serviço também estão os conhecimentos técnicos do profissional. Isso não desvirtua o papel primordial de assistência técnica a quem solicita

22 Quanto ao mal-entendido provocado pelo ideal de gratuidade em relação à importância dos defensores das partes no processo, cfr. Id., La giusta mercede dell'avvocato ecclesiastico, in AA. VV., Prassi e sfide dopo l'entrata in vigore del m.p. Mitis Iudex Dominus Iesus e del rescriptum ex audientia del 7 dicembre 2015, 129-138. 
o serviço profissional. A "natureza institucional do processo" funda-se em dita conjunção, desde a qual não se deve presumir fissuras presumidamente irremediáveis entre o serviço à verdade objetiva, que é do interesse do ordenamento, e o serviço à verdade subjetiva do próprio assistido, pois esta é o caminho obrigatório a ser percorrido para se chegar àquela.

É, sobretudo, na preparação da causa onde com maior clareza se coloca a corresponsabilidade institucional que caracteriza a deontologia da advocacia canônica, conjugando sua função de serviço à verdade e as teses da parte assistida na perspectiva de missão. $\mathrm{O}$ dever de corresponsabilidade recolhe tudo o que se relaciona com o compromisso institucional do advogado em buscar a verdade. Sua projeção ética no âmbito canônico é superior à de outros foros, porque seria redutivo limitar este dever à simples veracidade da atuação profissional. Os objetivos canônicos vão além, pois pedem uma verificação corresponsável durante o processo, sobretudo, no estudo prévio da causa.

2.3.2. O ideal de gratuidade e a liberdade de opção na designação do advogado

As assembleias sinodais de 2014 e 2015 ao destacarem a necessidade de se preparar mais pessoas, clérigos e leigos, para tornar acessível a realização deste serviço eclesial ${ }^{23}$, nela incluíram a preparação de defensores especializados em direito canônico, cujo trabalho profissional pode e deve ser entendido como um trabalho também pastoral. A livre escolha do próprio defensor é um direito que o CIC reconhece às partes (cân. 1481), razão pela qual a sua intervenção não deve ser vista de maneira contraposta ao objetivo da acessibilidade, mas, sim, como facilitação do recurso ao processo.

A acessibilidade e facilitação mencionadas exigem uma referência ao ideal da gratuidade. Nos textos sinodais, o ideal da "possível gratuidade" foi colocado em relação com os serviços de informação e consulta anteriores ao processo. A possível extensão do ideal de gratuidade a todo procedimento obriga a distinguir entre a gratuidade que a estrutura institucional da Igreja consiga oferecer (os custos proces-

${ }^{23}$ Cfr. Relatio Synodi 49 y Relatio finalis 82. 
suais) e a que se refere à justa compensação dos defensores das partes. Em relação é isso, além dos princípios estabelecidos na deontologia canônica, é práxis majoritária na Igreja, como na maioria dos sistemas jurídicos seculares, oferecer a gratuidade a quem, por razões objetivas, dela necessitar, seja através dos turnos de ofício entre os advogados admitidos no tribunal, seja através da figura de um patrono estável. A indevida intromissão institucional na designação dos advogados das partes, obstaculizando a intervenção daqueles que foram designados por elas, além de colocar em sério risco o reconhecimento externo da atividade judicial da Igreja (e das sentenças eclesiásticas), compromete gravemente a posição de imparcialidade que toda autoridade judicial a todo custo deve manter.

\section{A justiça no proceder nas causas penais}

Quanto às causas penais, o ponto de partida de nossa reflexão é a existência de algumas urgências dolorosas que requerem soluções jurídicas eficazes e rápidas, mas que favorecem um abandono da técnica judicial em favor de outras estratégias processuais presumidamente menos expostas aos riscos da ineficácia e lentidão ${ }^{24}$. Daí o recurso a processos penais extrajudiciais em uma abundância maior do que o permitiriam as normas, consentindo-se que se recorra a tais vias, inclusive, para a imposição de sanções graves e perpétuas. De minha parte, considero que para enfrentar essas urgências é necessário percorrer o caminho inverso, tendo em vista os vínculos existentes entre decisão verdadeira e juízo legítimo. Creio inaceitável permitir que se diminuam as garantias processuais do imputado com o único fim de salvar a instituição, dando-se, assim, mensagens exemplares para comunidade e a sociedade ${ }^{25}$.

24 Para uma exposição mais ampla, cfr. M. J. Arroba Conde, Justicia reparativa y derecho penal canónico, en Anuario de derecho canónico 3 (2014), 31-51.

Sobre a necessidade de superar estas abordagens no direito penal canônico e nos correspondentes processos, cfr. M. Riondino, Giustizia riparativa e mediazione nel diritto penale canonico, Città del Vaticano 2011; o autor destaca a importância de ampliar os objetivos e as estratégias da investigação prévia, sem marginalizar totalmente o presumido autor do delito, e da valorização da atenção à vítima quando se tratar de pessoa física. Em relação ao recurso não obrigatório às san- 
Com isso chegamos a tratar aquilo que pode ser considerado o limite principal das normas vigentes, isto é, as condições demasiadamente genéricas que hoje permitem optar pela via extrajudicial, deixando-se de lado as exigências rigorosas que decorreriam da abertura de um juízo penal. Resulta bastante claro que as condições para se realizar o processo extrajudicial são demasiadamente genéricas, uma vez que a lei exige, apenas, que haja causas justas ${ }^{26}$. É verdade que ao exigir, de forma tão débil, a existência de causas justas, não resta a menor dúvida que o ordenamento canônico tem uma preferência pelo processo judicial. Todavia, sobre o significado de causas justas, que em relação às graves e gravíssimas representam o grau inferior na hierarquia de motivos que o ordenamento canônico estabelece quando permite derrogar normas habituais, as interpretações são ambíguas e nem todas elas aceitáveis ${ }^{27}$. A norma exige que as causas se refiram a fatos que constituam um obstáculo direto para a celebração do juízo penal e, portanto, não parece aceitável converter dita causa em motivos que presumidamente aconselhem seguir o procedimento extrajudicial, como poderia ser o de uma maior rapidez em apresentar a solução ou a urgência em impor uma sanção ${ }^{28}$. Às vezes se aduz como causa justa $o$ possível escândalo que na comunidade local comportaria um processo judicial, dando-se por certo que constituiria um escândalo menor para os fiéis impor penas sem juízos e nem garantias ${ }^{29}$.

Merece uma menção à parte a falta de pessoal preparado que, certamente, constitui um sério obstáculo para que se possam celebrar juízos penais, mas não é aceitável transformar isso em motivo para sistematicamente evitá-los, seja porque nada tem a ver com as peculia-

ções em âmbito canônico, cfr. A. Titomanlio, La non esigibilità. Il diritto penale canonico snodo tra libertà morale e dignità della persona, Città del Vaticano 2016.

26 Para um estudo monográfico desta problemática, cfr. G. Giovanelli, Quoties iustae obstent causae. Dal processo penale amministrativo al processo penale giudiziale straordinario. Città del Vaticano 2016.

27 Cfr. G. Puntillo, Decreto penale extragiudiziale canonico e diritto di difesa, Città del Vaticano, 2010, 62 ss. A respeito dos conceitos gerais, cfr. R. Genuin, Giusta, grave e gravissima causa nel diritto processuale canonico, Roma 1996.

28 Contra essa ideia, cf. P. Ronzani, La pena ecclesiale, Padova, 2004, 151-152.

29 Contra essa errada interpretação, cf. Z. Grocholewski, Presentazione, en Z. Suchecki, Il processo penale canonico, Città del Vaticano, 2003, 5-9. 
ridades do caso, ao qual deveriam se referir as causas justas, seja porque se deve considerar bem mais como situação injusta a sofrida pela comunidade (e, portanto, como motivo justo), seja porque o ordenamento canônico, ao regular com flexibilidade a competência judicial, permite prover a carência de juízes sem autorizar com isso que se burlem as garantias imprescindíveis que oferece a comprovação judicial de fatos delicados ${ }^{30}$. É certo que a lei universal, mesmo que haja causas justas, não permite impor por decreto extrajudicial penas perpétuas, entre as quais se inclui a demissão do estado clerical. Todavia, tal proibição pode ser superada (e hoje com muita frequência) através da concessão de permissões ou faculdades especiais ${ }^{31}$.

Enquanto extrajudicial, a possibilidade de o Ordinário proceder por decreto poderia ser considerada, ao menos em sua aparência, como a opção mais facilmente harmonizável com os valores vinculados, na esfera penal, a procedimentos tais como a medição e a justiça reparativa. Todavia, deve-se recordar que o recurso a essas estratégias extrajudiciais está intimamente ligado à finalidade de se evitar impor sanções privativas de direito, sem diminuir com isso a exigência de uma adequada comprovação dos fatos e favorecendo o contato entre o réu e a vítima. Estas três dimensões não possuem um lugar adequado no sistema canônico, onde o recurso à via extrajudicial não possui limites em razão da natureza privativa das penas (mas somente de sua perpetuidade). Nesta via, as normas que devem reger a obrigatória comprovação dos fatos ficam reduzidas a uma necessidade demasiadamente genérica de se recolher as provas, antes da emissão do decreto, quase nos mesmos termos fixados pelo cân. 50 para qualquer outro

30 A respeito da obrigatória interpretação do instituto da competência judicial no processo canônico desde a tutela da comprovação da verdade e não desde valores comuns a outros ordenamentos (como o da distribuição territorial do poder) me remeto aos temas 9 e 10 do meu livro Diritto processuale canonico, 97-136.

31 A Congregação para a doutrina da fé pode conceder autorização para se tratar pela via extrajudicial de alguns processos penais, sem excluir que neles se proponha a imposição da pena de demissão do estado clerical. A isso se acrescentam as conhecidas faculdades para tratar pela via administrativa a questão da demissão do estado clerical que recentemente foram concedidas à Congregação para a Evangelização dos povos e para a Congregação do clero. 
decreto administrativo e onde não se faz qualquer menção explícita à participação da vítima ${ }^{32}$.

É preciso salientar que a lei, embora sem fugir do âmbito de um procedimento muito sumário, estabelece uma notável diferença em relação aos decretos extrajudiciais e ao procedimento prévio dos demais decretos. Nestes últimos, a lei dispõe que se escute, mas apenas na medida do possível, aquele que poderia se ver afetado em seus direitos pelo conteúdo do mesmo decreto. Nos primeiros, a decisão deve ser precedida da comunicação ao réu das acusações e das provas, razão pela qual a obrigação de ouvi-lo, antes ditar a resolução, não deve ser entendida como sujeita a exceção alguma, a não ser no caso de sua eventual ausência do procedimento.

\subsection{Algumas propostas contra o risco de injustiça no proceder}

Podem-se formular algumas propostas de iure condendo com a convicção de que trariam um aperfeiçoamento do sistema vigente no horizonte de uma justiça penal reparativa, sem comportar, ao mesmo tempo, revoluções significativas na atual legislação processual. Assinalo três possíveis propostas de aperfeiçoamento.

A primeira proposta tem relação com as condições para se optar pela via extrajudicial. O recurso a esta via deveria se limitar a dois tipos de situações. A primeira, como a lei já o permite, àqueles casos em que as circunstâncias consintam prover com resoluções de natureza não privativa, como as penitências ou outras obras alternativas de significado reparador. Nem sempre é possível delimitar em cada caso o suposto delitivo, razão pela qual pode parecer uma quimera pensar em uma reação correspondente e adequada para prover o conjunto de finalidades das sanções com a mesma antecipação. Todavia o ordenamento canônico não impede de prover com medidas reparativas e alternativas sequer quando estabelece uma pena obrigatória para determinados delitos ${ }^{33}$. Um segundo tipo de situação na qual o recurso à

32 Considero muito acertadas as considerações formuladas pelo Prof. M. Riondino, Giustizia riparativa, 178-184.

33 Assim o estabelece o cân. 1344 em determinados supostos entre os quais cabe mencionar a eventual sanção imposta no foro civil. Sobre isso, cfr. M. Riondino, 
via extrajudicial resulta menos exposto aos inconvenientes que supõe este procedimento sumário são os casos em que existam provas irrefutáveis do delito, sendo suficiente colocá-las diante do réu para garantir os seus direitos, concedendo-lhe o tempo que se considere necessário para a sua defesa e possível refutação das provas. É uma condição já existente no cânon paralelo do código oriental que, nesta matéria, resulta muito mais adequado que o código latino ${ }^{34}$.

A segunda proposta de aperfeiçoamento se refere a uma maior concretude dos critérios de avaliação das provas de acordo com o cân. 1572, estabelecendo-se que devam reger o discernimento do ordinário antes de se emanar o decreto penal extrajudicial e aos quais o mesmo ordinário deverá obrigatoriamente fazer referência específica e detalhada nas motivações de sua decisão ${ }^{35}$. A referência concreta às provas e ao seu sucessivo reflexo nas motivações do decreto permitiria que, ao menos, embora talvez tarde, o réu pudesse recorrer com maior pertinência contra os fatos ou contra as avaliações efetuadas pelo ordinário, de modo que ficassem resolvidas eventuais lacunas do procedimento extrajudicial relativas às garantias do acusado.

Uma terceira proposta de aperfeiçoamento é a de incluir expressamente a mediação desenvolvendo em âmbito penal o que o cân. 1446 já permite ser feito. Isso exigiria admitir que o imputado sempre possa propor uma conduta reparativa antes que se conclua o processo judicial ou administrativo. Se o juiz, ou o ordinário, consideram que tal conduta é adequada para conseguir as finalidades mencionadas pelo cân. 1311, poder-se-ia declarar extinto o delito ou, ao menos, levar em consideração dita disponibilidade no momento de determinar a sanção. Ao mesmo tempo, uma vez que tenha sido comprovada a culpabilidade do imputado, o superior, ou o juiz, podem propor a ele, à

Connessione tra pena canonica e pena statuale, en Aa. Vv., Questioni attuali di diritto penale canonico, Città del Vaticano, 2012, 199-225.

34 Pode-se facilmente apreciar a diferença entre o que estabelecem o cân. 1342 e o CCEO no cân. 1402.

35 Para diminuir o risco de transformar o principio da livre avaliação das provas em avaliação arbitrária é preciso reforçar o vínculo entre a avaliação da prova e a redação das motivações da decisão. Sobre este ponto, cf. M. J. Arroba Conde, Convincimento, certezza e motivazione: l'esperienza canonica, en Criminalia, 2013, 163-180. 
vítima ou a quem possa representar adequadamente o bem jurídico ofendido com o delito, o acesso a um procedimento de mediação penal conduzido por pessoas dignas, designadas pelo ordinário. O que as partes declararem perante o mediador ficará submetido ao secreto e não pode ser utilizado caso, sucessivamente, venha a ser aberto o processo, embora o mediador deva informar ao juiz ou ao ordinário acerca do resultado da mediação e das condutas reparativas propostas ou já em andamento. Também neste caso, se o juiz ou o ordinário consideram positivo o resultado da mediação no respeito às finalidades mencionadas pelo cân. 1311, poderia declarar extinto o delito ou, ao menos, tê-lo em consideração no momento de declarar a sanção ${ }^{36}$.

\subsection{Os riscos do excessivo recurso à via extrajudicial}

O recurso à via extrajudicial comporta três riscos principais:

O primeiro é que o processo extrajudicial pode privar o imputado de certas garantias, embora seja igualmente necessário evitar no juízo penal os excessos na interpretação do formalismo processual, cuja aplicação não pode resultar paralisante para a administração da justiça penal. Há casos sonoros e dolorosos em que se verificou uma postura excessivamente formalista, tanto na questão substancial, como na processual. Penso em um conhecido caso em que o excesso de formalismo substancial recaía na fixação dos extremos de um delito de plágio $^{37}$. O que costuma ser considerado como um conjunto de complica-

36 O quanto indicado nesta terceira proposta foi objeto da reflexão realizada pelo grupo de professores do Institutum Utriusque Iuris por ocasião das contribuições para a revisão do atual Livro VI do CIC.

37 A isso se acrescente o excesso de formalismo processual que consiste em uma interpretação pouco equilibrada do direito de defesa, visto que não se negou ao acusado o direito de ser ouvido, embora isso não tenha sido feito antes da primeira determinação que se tomou contra si, porque, embora tivesse sido citado, não se apresentou, alegando estar em viagem. $\mathrm{O}$ caso se resolveu com uma decisão absolutória. Trata-se da única sentença escrita pelo então Cardeal Ratzinger em sua condição de juiz membro do Tribunal da Assinatura Apostólica (cf. Signatura Apostolica, coram Ratzinger, sentencia Romana, 27.10.1984, Dimissionis a munere docendi, en Il diritto eclesiástico 96, 1985, 260-270). Foi uma sentença dolorosa, na qual o juiz ponente, que realizava pela primeira vez esta função, apresentou a sua irrevogável demissão, pois lhe resultava muito difícil assumir 
ções ou um excesso de formalismo no desenvolvimento do processo judicial penal, não pode ter por culpado o sistema, mas, sim, a sua falta de aplicação e inadequada compreensão no que se refere à rigorosa comprovação dos fatos, desde uma discussão sincera e transparente, sem que outros falsos temores possam justificar atuações carentes de qualidade e de credibilidade jurídica. É certo que, entre os perigos de incorrer em atitudes passivas ou brandas no exercício do poder coativo, costuma se mencionar, juntamente com a complexidade dos objetivos que devem ser assegurados na imposição das sanções, a incerteza dos ordinários sobre o procedimento que deva ser utilizado para alcançá-los. Por isso a Santa Sé, no Diretório sobre o ministério pastoral dos Bispos, reivindica com clareza a necessidade de superar esta passividade em situações que envolvam riscos de desorientação para a comunidade eclesial a eles confiada, solicitando-lhes a reagir com intervenções que conjuguem a caridade e a firmeza ${ }^{38}$. Tudo isso exige uma preparação suficiente dos Bispos e uma preparação específica em direito penal por parte de outros fiéis, clérigos ou leigos, que possam colaborar com eles.

O segundo risco que a ausência de processos judiciais provoca e que caracteriza a atualidade eclesial em matéria penal, é o de se incorrer inconscientemente na tentação de prover com resoluções para se mandar mensagens exemplares na defesa de interesses institucionais. Não é lícito terminar por confundir a obrigação objetiva de restabelecer a justiça que identifica a Igreja, afetada pelo delito, com a tutela radical da tranquilidade institucional, querendo com isso evitar, através da imposição precipitada de sanções, que a instituição possa ser

em seu ditame semelhantes derivações formalistas, tendo até então passado a maior parte de sua vida cobrindo uma cátedra universitária de muito prestígio, desde a qual exerceu como autor de escritos conhecidíssimos em sua originalidade. Apesar da absolvição, o réu não foi reincorporado à sua cátedra universitária, pois se considerava que não podia regressar a ela, nem tanto pelo plágio realmente cometido, mas, sim, assim se disse, por outros motivos de conduta pedagógica que, talvez, nunca tivessem sido objeto de sincera comunicação entre ele e as autoridades da universidade, vítima de suas atuações. O réu, aceitando sua exclusão da universidade, obteve outras vantagens em sua posição eclesial, resultado que repugna ao mais elementar sentido de justiça reparativa.

38 Veja-se a respeito o $\mathrm{n}^{\mathrm{o}}$. 68 do Diretório da Congregação dos Bispos Apostolorum sucesores. 
acusada como corresponsável pelo delito. O Prof. Riondino adverte em seu estudo que a justiça que deve ser restabelecida com a sanção é a justiça salvífica que identifica a Igreja, da qual faz parte o réu, embora se demonstre culpável $^{39}$. Considerar inevitável a tutela do réu é ainda mais urgente que a comprovação real de sua culpa, razão pela qual não cabe exercer sobre ele pressões voltadas para a sua aceitação de decisões gravosas, dizendo-lhe que o que está em jogo é um presumido bem da Igreja. Geralmente estas situações se verificam em relação a delitos que implicam, também, a jurisdição civil, sobretudo se esta já se pronunciou sobre o caso.

Quero chamar a atenção sobre os efeitos que às vezes comporta a celebração do processo penal na jurisdição estatal. Trata-se de uma circunstância que não deve ser interpretada como uma autorização para se evitar a abertura do processo canônico. A tal conclusão se poderia chegar, não somente por se ceder inconscientemente à pressão que desde fora é exercida sobre a Igreja, mas, talvez, por confusão na interpretação da norma que autoriza a não impor sanções canônicas quando se consideram suficientes aquelas impostas pelo poder civil. Não se pode cair neste erro, seja para aceitar a condenação, seja para acolher a absolvição do réu. Creio que, além das razões de direito substantivo que incidem na orientação estritamente canônica das penas, é preciso levar em conta possíveis razões diretamente processuais, especialmente no que se refere à avaliação das provas e a aquisição da devida certeza moral. Acredito que é imprescindível que a Igreja saiba e se atreva com valentia a tomar expressamente a devida distância das decisões da jurisdição estatal que tenham por fundamento uma produção de provas, ou uma avaliação delas, que não seja congruente com as normas do processo canônico e, de maneira especial, com as disposições que protegem as garantias que correspondem ao réu no curso de um processo judicial. Está claro que tampouco este segundo tipo de riscos se pode evitar caso não haja uma maior capacitação para celebrar processos judiciais penais ${ }^{40}$.

Concluo, assim, indicando o terceiro risco que implica a carência de processos judiciais na esfera penal. Refiro-me justamente à pul-

39 Cfr. M. Riondino, Giustizia riparativa, 60-64.

40 Em tal sentido se expressa, também, M. Riondino, Connessione..., 199-202. 
verização indireta das garantias conseguidas no novo código e que podem ser qualificadas como orientação da renovação normativa desde a centralidade da pessoa na vida e missão da Igreja. Em âmbito penal o peso da orientação personalista é possível ser apreciado no direito substantivo do Livro VI, onde a riqueza do patrimônio canônico mais genuíno se presta a conceber a sanção penal, tal como se indica na moderna doutrina, não apenas e nem somente como privação de um bem, mas, sim, como projeto que responsabiliza frente ao bem ${ }^{41}$. Todavia, creio que também no terreno processual, em concreto, nas disposições que regulam o processo penal judicial, é inegável o valor personalista contido em algumas novidades do código vigente.

Entre estas novidades cabe destacar as que se relacionam com os direitos do acusado em todo o desenvolvimento do processo e que não tem paralelo no código anterior, como a que impõe pedir ao acusado que nomeie um advogado ou, na falta dele, de lhe seja dado um (cân. 1723); a que proíbe renunciar à instância penal sem o consentimento do acusado (cân. 1724); a que confere a última palavra no debate ao acusado, ou a seu advogado (cân. 1725); a que obriga a dar uma sentença de absolvição se constar que não houve crime, mesmo quando a ação penal estiver prescrita (cân. 1726); a que garante o direito de apelar tendo em vista a demonstração da inocência, mesmo quando a decisão prescindiu da pena (cân. 1727); a que proíbe pedir juramento ao acusado, declarando, ao mesmo tempo, que este não tem a obrigação de confessar o delito ${ }^{42}$.

Não quero deixar de me referir ao processo penal pelos delicta graviora regulados pelo motu proprio Sacramentorum sanctitatis tutela, no qual se estabelecem as competências da Congregação para a doutrina da fé como Supremo Tribunal. Naquilo que se refere estritamente ao processo, não há porque temer qualquer diminuição da tutela do acusado. Poder-se-ia afirmar que esta diminuição se produz de forma indireta, ao contemplar-se a possibilidade, para mim desaconselhável, de proceder pela via extrajudicial, mesmo para impor a demis-

Cfr. Id., Giustizia riparativa, 54-57.

42 Para uma análise destas novidades, cf. E. M. Egan, I processi speciali, en Aa.Vv., Il nuovo codice di diritto canonico. Novità, motivazione e significato, Roma, 1983, 499. 
são do estado clerical. Considerando as condições estabelecidas para se proceder desta forma, não se pode afirmar que as normas do processo para tratar destes delitos tenham acarretado para o presumido autor do delito uma diminuição no nível de garantias que uma adequada orientação personalista requer. Ao mesmo tempo, são dignos de nota os avanços que estas normas contêm em relação à atenção que merece a vítima do delito, seja ela uma pessoa física, seja a comunidade eclesial em seu conjunto.

Cabe desejar uma melhora naquilo que diz respeito especialmente à comunicação com a comunidade. Valeria a pena avaliar se não seria melhor realizá-la com sujeitos distintos dos titulares do ofício com poder próprio e a quem está imediatamente sujeito o presumido autor do delito. Trata-se de discernir em cada caso aqueles que (por ser organismo colegial, ou por se tratar de uma pessoa ou de um ofício pessoal útil na causa concreta) possam ser representantes da comunidade enquanto vítima do delito. É indispensável uma correta comunicação, tanto para com o réu, quanto para com a comunidade, evitando comprometer sem necessidade a boa fama, mas, também, sem desnecessários obscurantismos. Com isso, se diminuiria os riscos de violar as garantias processuais do réu e, ao mesmo tempo, se reduziria a possibilidade de que o necessário segredo se converta em uma arma para que o réu, faltando com a verdade, possa contestar presumidas violações de seus direitos processuais ou, inclusive, alegar um desconhecimento das imputações que lhe foram atribuídas. Essa situação tem ocorrido com muita frequência, criando ainda mais confusão na comunidade e gerando dissensões.

\section{Conclusão}

Dentro da abordagem que aqui adotamos, cabe destacar outro dado de fundo relevante. Quero me referir à transformação que se foi gradualmente estabelecendo na concepção da autoridade eclesiástica em sua dimensão jurídica. Quero dizer que a convicção existente no passado, segundo a qual a autoridade eclesiástica acreditava ter uma responsabilidade moral direta, permitiu que ela empregasse métodos contrários a dignidade da pessoa, como a tortura, mesmo que com a 
intenção de alcançar vantagens para sua alma e sua consciência. Todavia, o CIC de 1917 ainda permitia que a autoridade procedesse, em certas ocasiões, sem as devidas garantias, como as estabelecidas ex informata conscientia e ratione pecati. O ponto mais débil desta concepção foi justamente esquecer o papel insubstituível da consciência das próprias pessoas, para, por meio delas, atuar no encalço dos objetivos últimos do ordenamento eclesial. A revalorização da consciência de cada fiel cristão, tal como se manifestou na redação dos Princípios que nortearam a renovação do primeiro CIC, levou a configurar o controle da atuação da autoridade justamente em relação aos procedimentos por ela empregados no cumprimento de sua missão. O professor Gherri não hesita em assinalar que a maior aquisição da renovação realizada com o CIC de 1983 foi a atenção dada aos procedimentos da autoridade no exercício do seu ofício ${ }^{43}$.

Embora essa reflexão sobre a necessidade de um correto procedimento decisório se refira, sobretudo, aos atos da autoridade em seu ofício, na esfera executiva, ela também tem sua relevância em relação à cultura processual. De fato, a tensão entre a legitimidade do procedimento e a verdade na qual se baseia a decisão sobre direitos controversos é expressão significativa das consequências às quais pode conduzir o fortalecimento da dimensão procedimental de todo o setor jurídico e do direito em si. Ao ser reflexo de filosofias que se dizem neutras em relação aos conteúdos, alguns acreditam que tal fortalecimento seja uma forma de compensar a atual falta de confiança que o conceito de direito natural hoje gera, cujo declínio sugere orientar-se para valores mais acessíveis, como a utilidade social ${ }^{44}$. Em sua versão mais extrema, esta tendência implicaria que as resoluções judiciais sejam consideradas legítimas, não em razão de seu conteúdo (ou seja, de sua fundamentação em fatos verdadeiros), mas do mecanismo processual utilizado para pronunciá-las ${ }^{45}$. Isso certamente geraria um retrocesso cultural contra o qual vale a pena combater, sublinhando o papel

43 Cfr. P. Gherri, Introduzione al diritto amministrativo canonico. Metodo, Milano 2018, 254 ss.

44 Cfr. N. Lhumann, Procedimenti giuridici e legittimazione sociale, Milano 1995, 148

45 Cfr. M. Taruffo, La semplice verità. Il giudice e la costruzione dei fatti, Bari 2009, 100. 
fundamental das motivações, tanto para as decisões que correspondem ao juiz no transcurso do processo, quanto para a decisão final.

$\mathrm{O}$ risco de desnaturalizar os valores assegurados pelo procedimento na administração da justiça, caindo-se em uma indevida ênfase do mesmo, pode derivar da indevida insistência a respeito da natureza autônoma da relação processual, enquanto pertencente ao direito público, em relação à substancial, enquanto objeto da controvérsia.

A tutela do direito substancial através da comprovação judicial não pode sofrer a intromissão da relação processual ou das regras meramente processuais, esquecendo e, inclusive, contradizendo, a função mais alta do processo que não é outra que a de ser um instrumento ulterior de tutela das relações jurídicas substanciais, mas exatamente, da conformidade de ditas relações à lei, de forma que a decisão judicial resolva sua possível desconformidade e a inobservância do direito. Diante de riscos assim Carnelutti lançou seu conhecido grito de alerta: "Voltemos ao juízo". Voltar ao juízo não significa esquecer o peso específico que as normas processuais possuem em si mesmas para resolver e comprovar a questão de fundo. Voltar ao juízo não significa negar e nem obscurecer a autonomia do processo, de suas regras e de suas relações jurídicas. Trata-se bem mais de evitar contraposições e, portanto, de assegurar que a autonomia das regras do processo, relativas aos preceitos de direito substancial, permita ao processo cumprir sua função instrumental e, portanto, conseguir que o pronunciamento do juiz possa ocupar o lugar da inobservância das normas, impedindo que um ato meramente processual ratifique esta última.

\section{Bibliografia}

A. Titomanlio, La non esigibilità. Il diritto penale canonico snodo tra libertà morale e dignità della persona, Città del Vaticano 2016.

Concilium Matisconense II, Canon VII, en J.D. Mansi (ed.), Sacrorum Conciliorum nova et amplissima collectio, IX, rist., Graz, 1960, coll. 952-953; Canon XII, in ivi, coll. 954-955.

E. M. Egan, I processi speciali, en Aa.Vv., Il nuovo codice di diritto canonico. Novità, motivazione e significato, Roma, 1983, 499. 
G. Giovanelli, Quoties iustae obstent causae. Dal processo penale amministrativo al processo penale giudiziale straordinario. Città del Vaticano 2016.

G. Puntillo, Decreto penale extragiudiziale canonico e diritto di difesa, Città del Vaticano, 2010.

J. Belda, El ministerio judicial del Obispo hasta el surgimiento de la Lex Christiana (ss. I-IV), en Anuario de Derecho Canónico 4 (2015), 387-401.

J. Ochoa, La figura canónica del procurador y abogado público, en M. Basso (ed.), Opus Iustitiae Pax. Miscellanea in onore del prof. Xavier Ochoa, Città del Vaticano 1990, 209-241.

M. J. Arroba Conde - C. Izzi, Pastorale giudiziaria e prassi processuale nelle cause di nullità del matrimonio, Cinisello Balsamo 2017.

M. J. Arroba Conde - M. Riondino, Introduzione al diritto canonico, Milano (2 ed.), 2017.

M. J. Arroba Conde, Convincimento, certezza e motivazione: l'esperienza canonica, en Criminalia, 2013, 163-180.

M. J. Arroba Conde, Deontología forense canónica, en Curso de derecho matrimonal y procesal canónico para profesionales del foro, XIX, Salamanca 2009,31-65.

M. J. Arroba Conde, Diritto processuale canonico, Roma ( $6^{\mathrm{a}}$ ed.), 2012.

M. J. Arroba Conde, Giusto processo e peculiarità culturali del processo canonico, Roma 2016.

M. J. Arroba Conde, Justicia reparativa y derecho penal canónico, en Anuario de derecho canónico 3 (2014), 31-51.

M. J. Arroba Conde, La pastoral judicial y la preparación de la causa en el motu proprio Mitis Iudex Dominus Iesus, en M. E. Olmos Ortega, Procesos de nulidad matrimonial tras la reforma del Papa Francisco, Madrid 2016, 63-82. 
M. J. Arroba Conde, La relazione tra potestà giudiziale episcopale e uffici tecnici nel processo brevior, en Av.Vv., Studi in onore di Carlo Gullo, Città del Vaticano 2018, 777-798.

M. Riondino, Connessione tra pena canonica e pena statuale, en Aa. Vv., Questioni attuali di diritto penale canonico, Città del Vaticano, 2012, 199-225.

M. Riondino, Giustizia riparativa e mediazione nel diritto penale canonico, Città del Vaticano 2011.

M. Taruffo, La semplice verità. Il giudice e la costruzione dei fatti, Bari 2009.

N. Lhumann, Procedimenti giuridici e legittimazione sociale, Milano 1995.

P. Gherri, Introduzione al diritto amministrativo canonico. Metodo, Milano 2018.

P. Gherri, Lezioni di teologia del diritto canonico, Città del Vaticano 2004.

P. Ronzani, La pena ecclesiale, Padova, 2004.

R. Genuin, Giusta, grave e gravissima causa nel diritto processuale canonico, Roma 1996.

Signatura Apostolica, coram Ratzinger, sentencia Romana, 27.10.1984, Dimissionis a munere docendi, en Il diritto eclesiástico 96, 1985, 260-270.

Z. Grocholewski, Presentazione, en Z. Suchecki, Il processo penale canonico, Città del Vaticano, 2003, 5-9. 